Article

\title{
Assessing Alluvial Fan of Bergama Using High Resolution DEM Generated from Airborne LiDAR Data
}

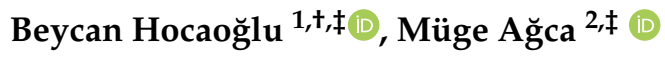 \\ İzmir Kâtip Çelebi Üniversitesi; beycan.hocaoğlu@ikcu.edu.tr \\ 2 İzmir Kâtip Çelebi Üniversitesi; mugekaan@gmail.com \\ * Correspondence: beycan.hocaoglu@ikcu.edu.tr; Tel.: +90-232-329 3535 / 8520 \\ † Current address: İzmir Kâtip Çelebi Üniversitesi, Sosyal ve Beşeri Bilimler Fak. Coğrafya Bölümü, Çiğli \\ İzmir / TÜRKIYE \\ $\ddagger \quad$ These authors contributed equally to this work.
}

\begin{abstract}
Topography represented by high resolution digital elevation models are able to inform past and present morphological process on the terrain. High resolution LiDAR data taken by the General Directorate of Map at the surroundings of the Bergama city shows great opportunities to understand the morphological process on alluvial fan on which the city is located and the flood plain of Bakırçay river near the alluvial fan. In this paper the LiDAR data collected in 2015 have been used to create DEM's to understand the geomorphological evolution of the alluvial fan and the flood plain around it. Since the proximal roots and medial parts of the alluvial fan have been the scene for a long human settlement most topographical traces of the morphological process have been distorted. Nevertheless, the traces of past and present morphological process at the distal fan which consist the contact zone with the flood plain are very clear on the DEM created from LiDAR data. The levees and some old courses of Bergama and Bakırçay rivers have been shown on the maps which are also important to understand the ancient roads which follows these levees.
\end{abstract}

Keywords: LiDAR, Bergama, Alluvial Fan, Geomorphology, Bakırçay River

\section{Introduction}

Western Anatolian coast of Turkey, the tectonics depressions extending in the East-West direction and is composed of streams flowing over these depressions. Flood plains created by sediments carried by rivers have shaped agricultural areas sufficient to feed large population masses throughout history. Due to the agricultural richness of the flood plains, these areas have attracted people throughout history. Therefore, in each of these basins where Bakırçay, Gediz, Küçük Menderes and Büyük Menderes rivers flow, there is more than one city of great importance such as Bergama, Sard, Ephesus, and Milet in ancient times. Flood plains are current dynamic formations with prolonged intense human settlement. Therefore, these areas have made special importance in terms of emphasizing human-environment interaction in the historical process.

The past and present environmental processes have been recorded on the morphology of the alluvial fans [1] [2]. Hence, detailing research on the morphology of alluvial fans has great importance to understand and to interpret present environmental processes and past environmental changes [3]. Alluvial fans are one of the most preferred places for settlement, especially in Western Anatolia, since they are at the transition zone between the steep slopes of the mountains and swampy flood plains. Alluvial fans allocate the most favorable conditions of both of steep slopes and swampy flood plains while abstain their unfavorable conditions [4]. On the other, the population concentrated at alluvial 
fans are subject to the risk on environmental process that generate the fan itself such as debris flows and earthquakes [5]

LiDAR (Light Detection and Ranging) technology offers the most detailed mapping technology which helps to understand and interpret the morphological evaluation and its interaction with human settlement [6]. LiDAR data has been used to determine land-slides [7] and in the restoration of river geomorphology [8] in a morphological sense. In this research detailed topographical map created from LiDAR data has been used to determine old river courses shaping the morphology of the alluvial fan.

Airborne LiDAR sensors are high resolution, active remote sensing tools that use lasers to measure the distance between the sensor and the object to be sensed [9] These systems distribute thousands of laser pulses per second and measure the return time needed for each pulse sent from the sensor to reach the ground and reflect the sensor [10] [11] [12]. This technology is useful for obtaining accurate and high-resolution measurements of surface elevations [13]. Compared to traditional techniques, e.g. field surveys and photogrammetry, LiDAR has proven an effective method for rapidly generating digital elevation model (DEM) and digital surface models (DSM) [14]. Detailed information can be extracted from LiDAR remote sensing such as accurate geometric $X, Y$, and $Z$ position of scattering elements which includes measurements of the ground surface [9]. These systems provide dense point cloud data related to the surface. Therefore; it allows us to generate high-resolution DEMs and DSMs with high accuracy. Slight elevation changes over a surface can be easily identified and the ground elevations can be mapped even in regions of dense vegetation because of multiple returns [15].

Over the last decade, there has been a significant increase in the use of LiDAR data for DEM and DSM generation as more reliable and accurate LiDAR systems are developed [16] [17] [18] [19] [20] [21] [22]. The use of airborne Lidar data in geographic areas is very common. The overall aim of this study is to perform a morphometric analysis of the alluvial fan located over the Bergama, one of the most important ancient settlements of the Bakırcay basin and has been intensely inhabited today, using airborne LIDAR data and to demonstrate its effect on human activities.

\section{Methodology}

\subsection{LiDAR Data Description}

Airborne LiDAR data were collected with the Optech Pegasus HA-500 system and obtained from the Turkish General Directorate of Mapping in LAS format. The LAS file format is a binary file format that maintains information specific to the LiDAR nature of the data while not being overly complex. LIDAR data were acquired over an area of $156 \mathrm{~km} 2$ on 20-21 October 2014. These data have been collected at a $1200 \mathrm{~m}$ height with a $50 \%$ overlap and a $35^{\circ}$ scan angle. The minimum number of points per square meter is 8 points. The quadratic mean error is calculated as $\pm 0.07 \mathrm{~m}$ [23].

\subsection{LiDAR Data Processing}

Before generating the DEM and DSM data, raw LiDAR data needs to be cleaned from noisy and duplicate points. First, CloudCompare 2.7 software was used to clean the dataset and merge all raw LiDAR point clouds. Raw LiDAR data contains return signals from features such as buildings, telephone poles, power lines, vegetation, ground classes, and even birds [24] [25]. The intensity-based feature relies on the reflected energy of the objects in the dataset. The desired target for DEM generation is bare earth points. Therefore, it is crucial to filter or extract bare earth points from LiDAR data. The LiDAR dataset was filtered to ground points using the Trimble Business Center 5.2 software. Various filtering methods have been developed to classify or separate raw LiDAR data into the ground and non-ground data. However, none of the automated filtering processes is $100 \%$ accurate so far [26]. Therefore, manual edits have been done on our filtering results. We have quite dense LiDAR data over the study area since there is a minimum of eight points per square meter. High-density data make it possible to represent terrain in much detail. The coordinates of our airborne lidar data are referenced to UTM Zone $35 \mathrm{~N}^{\prime}$, WGS-84. The LiDAR dataset was filtered to ground points (last returns) and DEM 
(Figure 1) was generated in $1 \mathrm{~m}$ resolution. Also, the DSM (Figure $\mathrm{x}$ ) was generated from all LiDAR points within the dataset. Slope, aspect, and hillshade data were generated from DEM and DSM data, respectively.

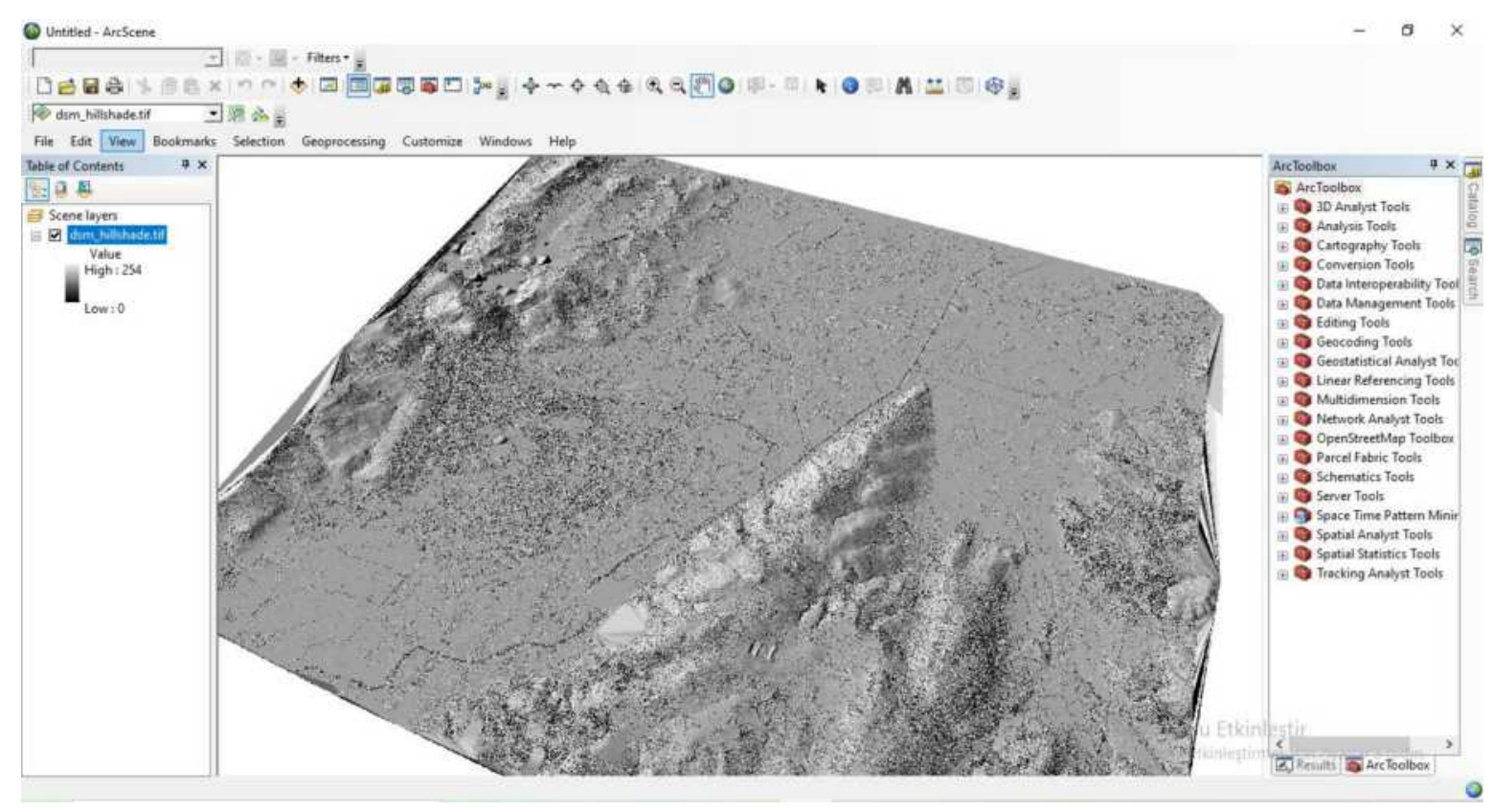

Figure 1. Location of Middle and Lower Bakırçay plains and its delta

\section{Geographical Setting}

The Bakırçay river, which begins to flow in the east with the name of Kocaçay, is passing through three different straits that divide the plain into four different sections until it pours into the Aegean Sea in Çandarlı Bay. The first strait is located between Kösedağ and Gölcük mountains near Soma and separates Kırkağaç plain in the rest of the plain. The second strait is not as pronounced as the first one. The city of Bergama is shaped by the Madra Mountain and the Yunt Mountains in the south and separates the Kınık Plain and the Lower Bakırçay Plain. The third strait separates the Lower Bakırçay plain and the Bakırçay delta from each other and is located at the foothills of Dikili and Yunt mountains. Besides, this strait also is located between Bozyer Tepe and Kabacalar Tepe (Figure 2). The tributaries of this strait coming from the north contribute more to the flow of Bakırçay. These streams are from east to west, Yağcılı stream, Ilıca stream, Kestel stream, Bergama stream, and Geyikli stream. The streams that come from the south to the Yunt mountains and merge with Bakırçay are Sinir stream, Koca Stream, Yayaköy stream, Kara stream, and Cumalı stream (Figure 3).

Geologically, the oldest formations of the basin are the formations of Upper Paleozoic and Triassic. The geological map of the Bakırcay Basin is given in Figure 4. This map was prepared from 1/500 000 scale geology maps. Sedimentary rocks of this period are seen in the north and west slopes of Yunt mountains in the south, near Zeytindağ and Kınık, and in the southern peaks of the Madra Mountain in the north. The plutonic granitoid Kozak Massif of Triyas completely covers the Kozak plateau of the Madra mountain. Limestone formations belonging to the Triassic, Jurassic and Cretaceous periods can be seen in Kösedağ, Gölcük Mountains and Şeydan mountain in the eastern parts of Bakırçay basin. The rest of the basin, other than the flood plain, consists of volcanic and sedimentary rocks belonging to the Lower and Middle Miocene. While volcanic rocks belonging to Lower and Middle Miocene dominate in the west of the basin, sedimentary clastic rocks dominate in the eastern part. 


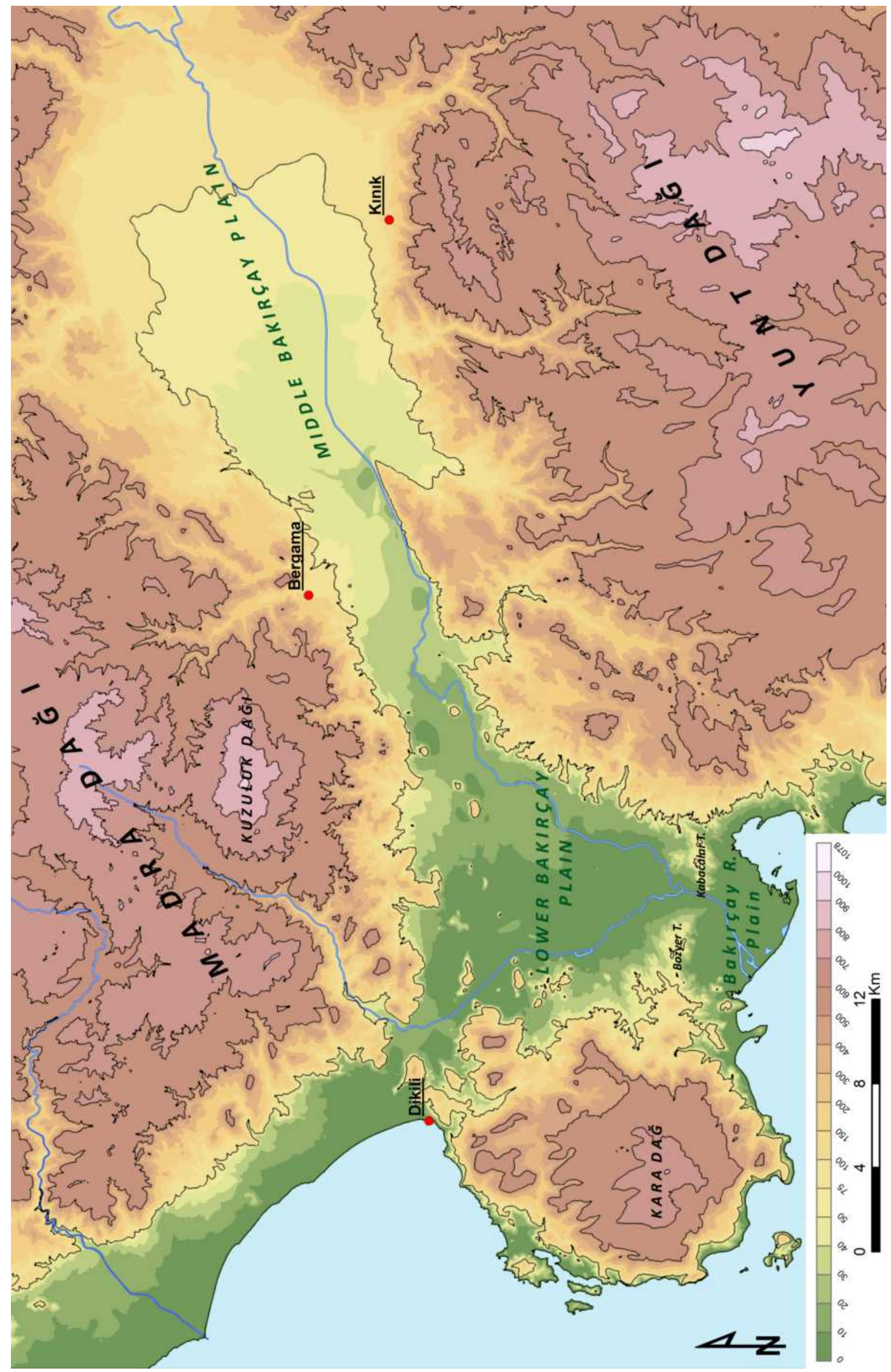

Figure 2. Location of Middle and Lower Bakırçay plains and its delta 


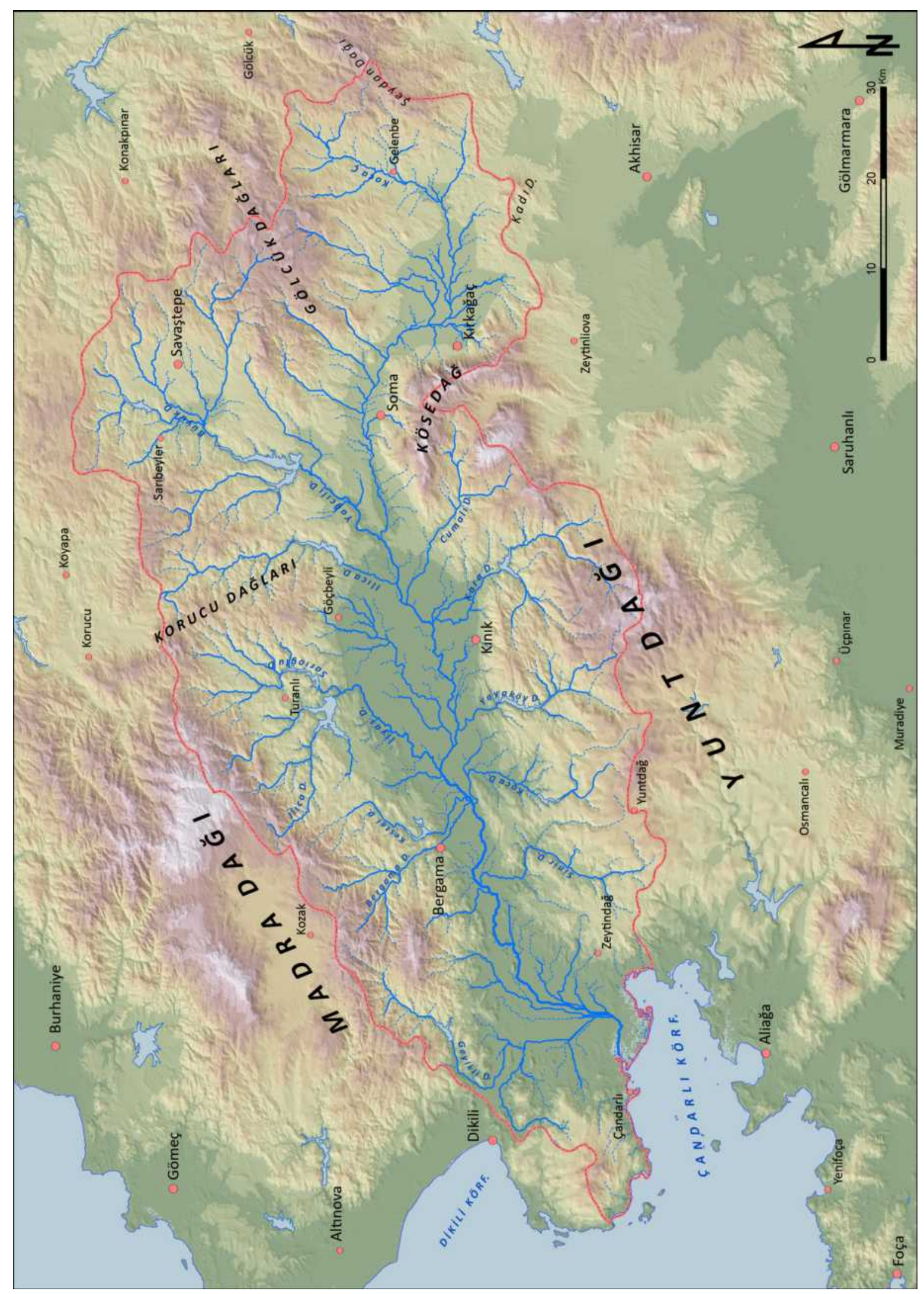

Figure 3. Catchment basin of Bakirçay River 


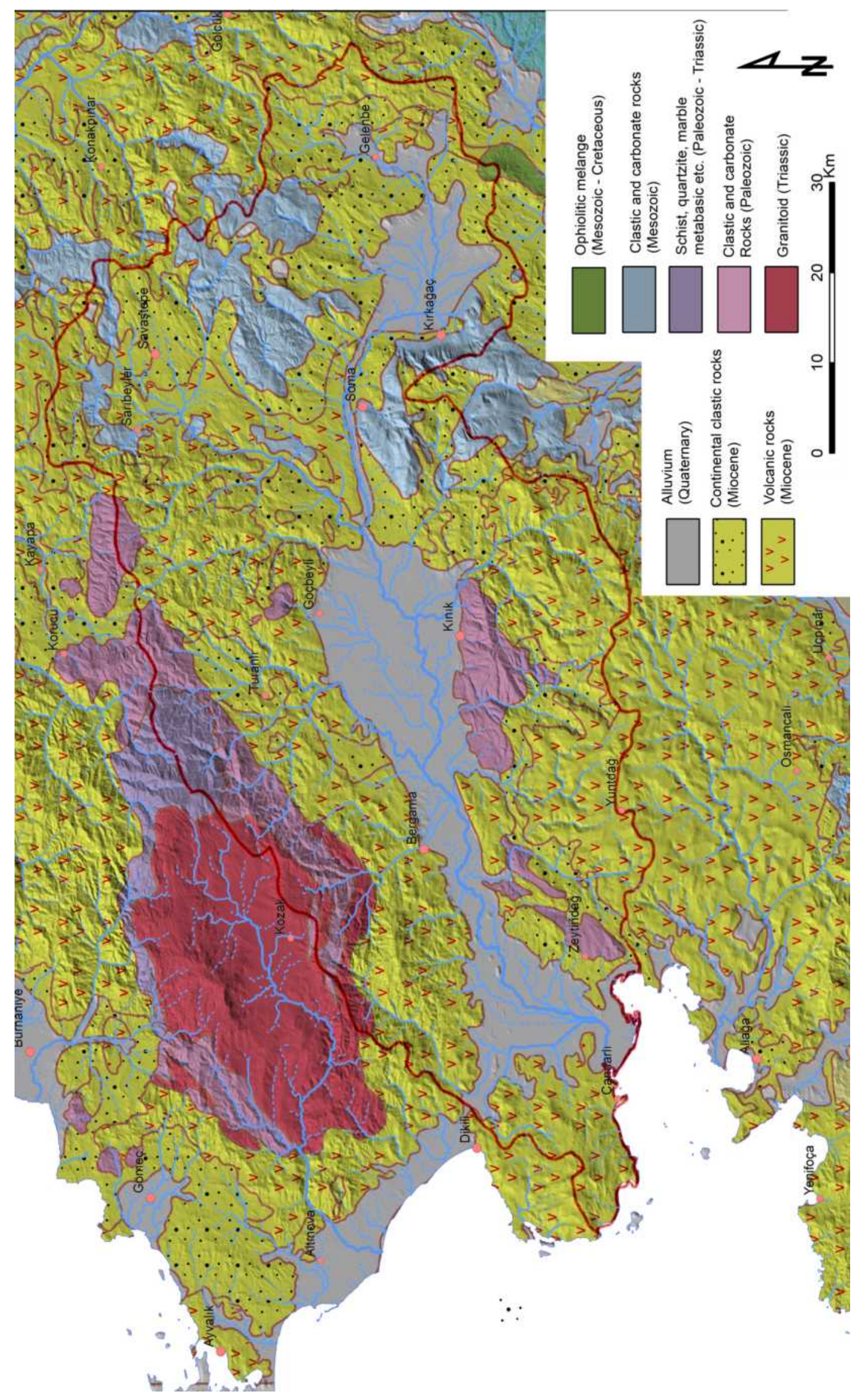

Figure 4. Geological map of Bakırçay river catchment basin 


\section{Alluvial Fan of Bergama}

Bergama alluvial fan is formed by the alluviums brought by the waters that take the spring from the Madra mountain of Bergama Creek and Kestel Creek in the north of the Bosphorus, which provides the transition between the middle Bakırçay plain and the Lower Bakırçay plain. With its relatively high position from the flood plain formed by the Bakırçay river, the alluvial fan, which is protected from the floods of the Bakırçay river, has had an extremely agriculturally favorable structure throughout the history and attracted the population of the region. This alluvial fan formed by Bergama creek and Kestel creek roughly compressed the Bakırçay river, that flows from east to west, to south side of the plain and pushed it towards the ridge between Sindel and Kaşıkçı villages. For this reason, as can be seen from historical sources, the area where the Bakırçay river shows the least bed change is located in this part of the plain. Figure 5 shows the drainage basins of the Bergama and Kestel's streams forming the Pergamon alluvial fan.

The alluvial fan was formed by the accumulation of sediments carried by the Bergama and Kestel streams flowing on the southern slopes of Madra mountain. Paleozoic limestones and Triassic metamorphic rocks are the oldest formations in the water basin of both streams. The granodiorite massive and Miocene volcanic formations in the Kozak plateau, dated to the Paleocene, are the most pre-Quaternary formations. The sands and volcanic tuffs formed by granodiorites as a result of exfoliation form the basic material of the alluvial fan. The Geological map of Bergama and Kestel streams water drainage basins is given in Figure 6. This map was prepared from 1/25 000 scale geology maps. 


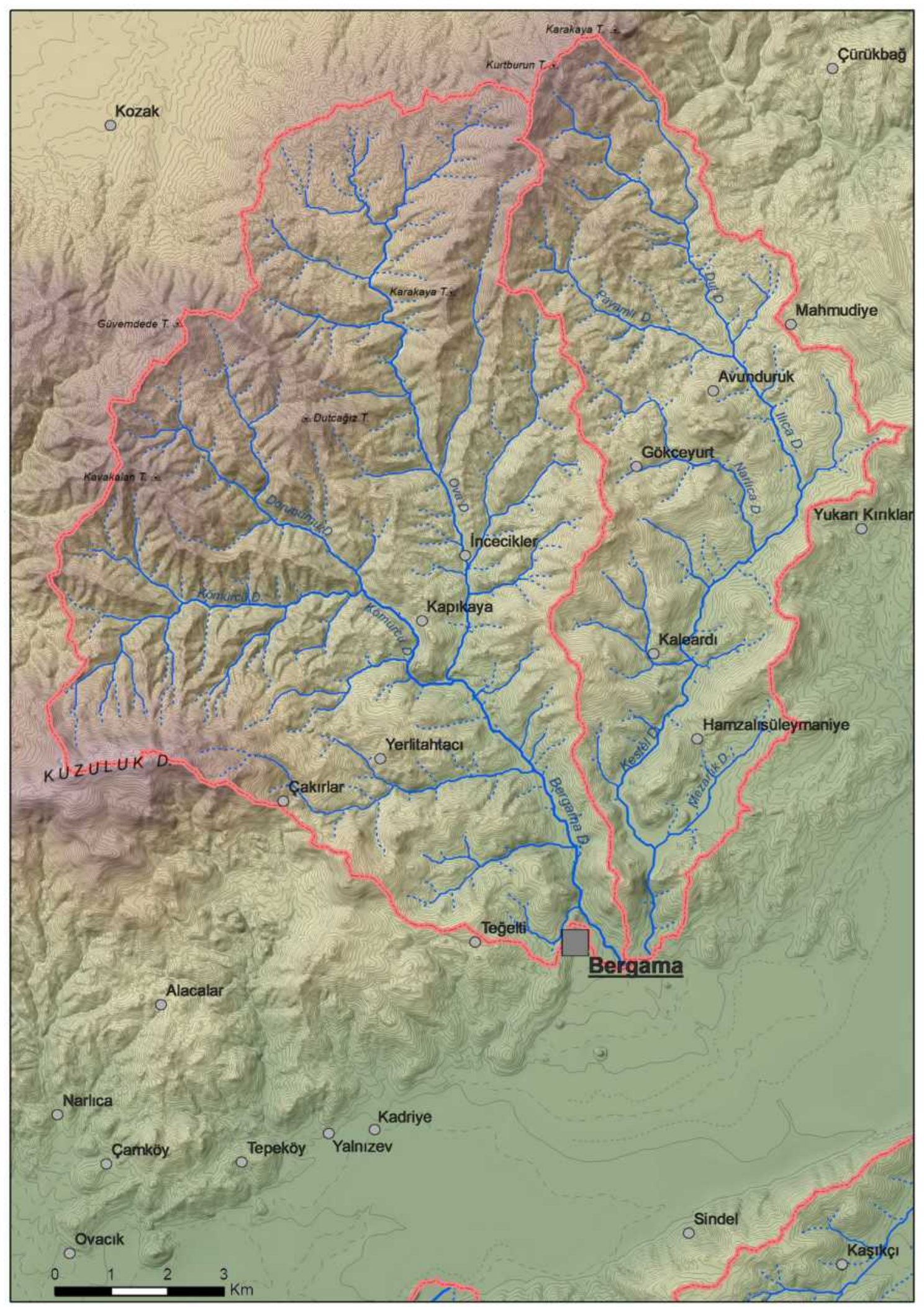

Figure 5. Drainage basin of Bergama and Kestel rivers 


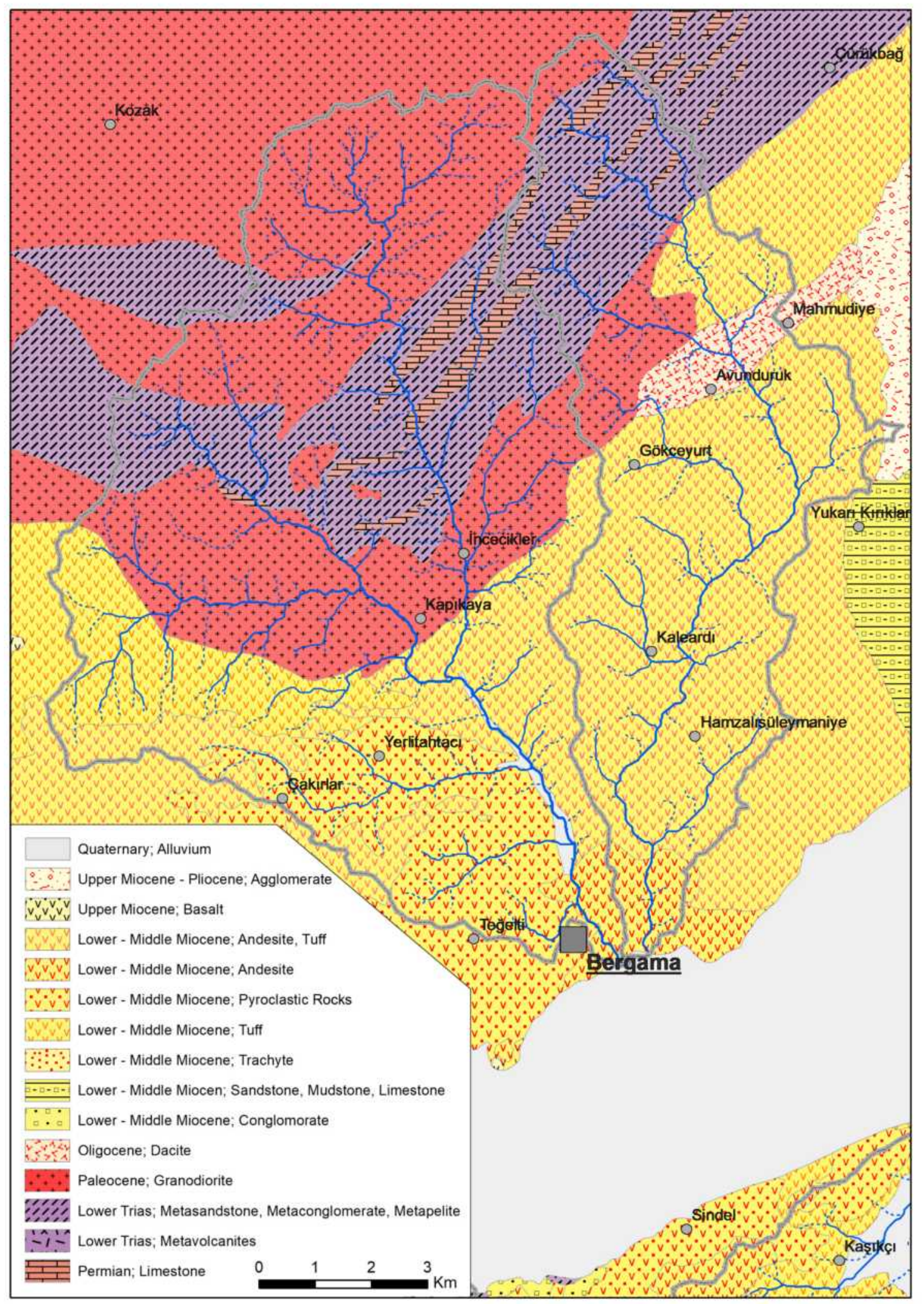

Figure 6. Geological map of Bergama and Kestel rivers' catchment basins 
waters from the first period when the fan started to form, and which are still active today, also affected the cone formed as a result of the accumulation activities in the area where the river was opened from the mountain to the plain. On the one hand, the alluvial fan formed by the accumulation of alluviums brought by the Bergama creek, on the other hand, began to erode its own bed over time with the tectonic rise. This formation process, which is seen in regions such as Anatolia, where tectonism is extremely effective, requires the alluvial fan to be examined in three sections.

The region where the Bergama alluvial fan is located is tectonically very effective. For this reason, the tectonic rising movements, which form the Madra mountain, where Bergama creek collects the waters from the first period when the fan started to form, and which are still active today, also affected the cone formed as a result of the accumulation activities in the area where the river was opened from the mountain to the plain. On the one hand, the alluvial fan formed by the accumulation of alluviums brought by the Bergama creek, on the other hand, began to erode its own bed over time with the tectonic rise. This formation process, which is seen in regions such as Anatolia, where tectonism is extremely effective, requires the alluvial fan to be examined in three sections.

1. Proximal fan, where the alluvial fan is first formed but the sediment accumulation process has come to a halt due to tectonic elevation and stream abrasion plays the main shaping role.

2. The most extreme part of the sediment spectrum (distal fan) where the sedimentation with fine-grained material plays the main shaping role, where the transition from the tandem to the flood plain floor.

3. The middle part (medial fan) where the transition between the root (proximal fan) and the tip (distal fan) is experienced.

\subsection{Proximal Fan}

The proximal part of the fan begins between the hill where Selçuk district of Bergama is located and the hill where the acropolis of Bergama is located. In this cutting, the height of the alluvial fan above sea level is above $110 \mathrm{~m}$. The ending of the accumulation process as a result of the tectonic uplift and the start of the erosion process is the current shaping factor in this cutting. Here, the depth of the bed eroded by Bergama Creek on the cone can reach $8 \mathrm{~m}$. Geomorphological interpretation from topography is difficult due to the intense urbanization in this part which is the main settlement of the city of Bergama. Also, three possible old stream beds can be observed radiating around radially, which gives the impression that they are formed by river abrasion in the rooted cutting. The first seam trail start from Atatürk boulevard and by following Cumhuriyet street and Bankalar street and have been proceeding into old city center. The second seam trail starts from Kayhan street in the south and connects with İsmet İnönü street in the north and continues to the north. The third easternmost trail starts with Kasapoğlu Street in the north and joins with the current bed of Bergama in front of the Red Basilica in the south (Figure 7). 


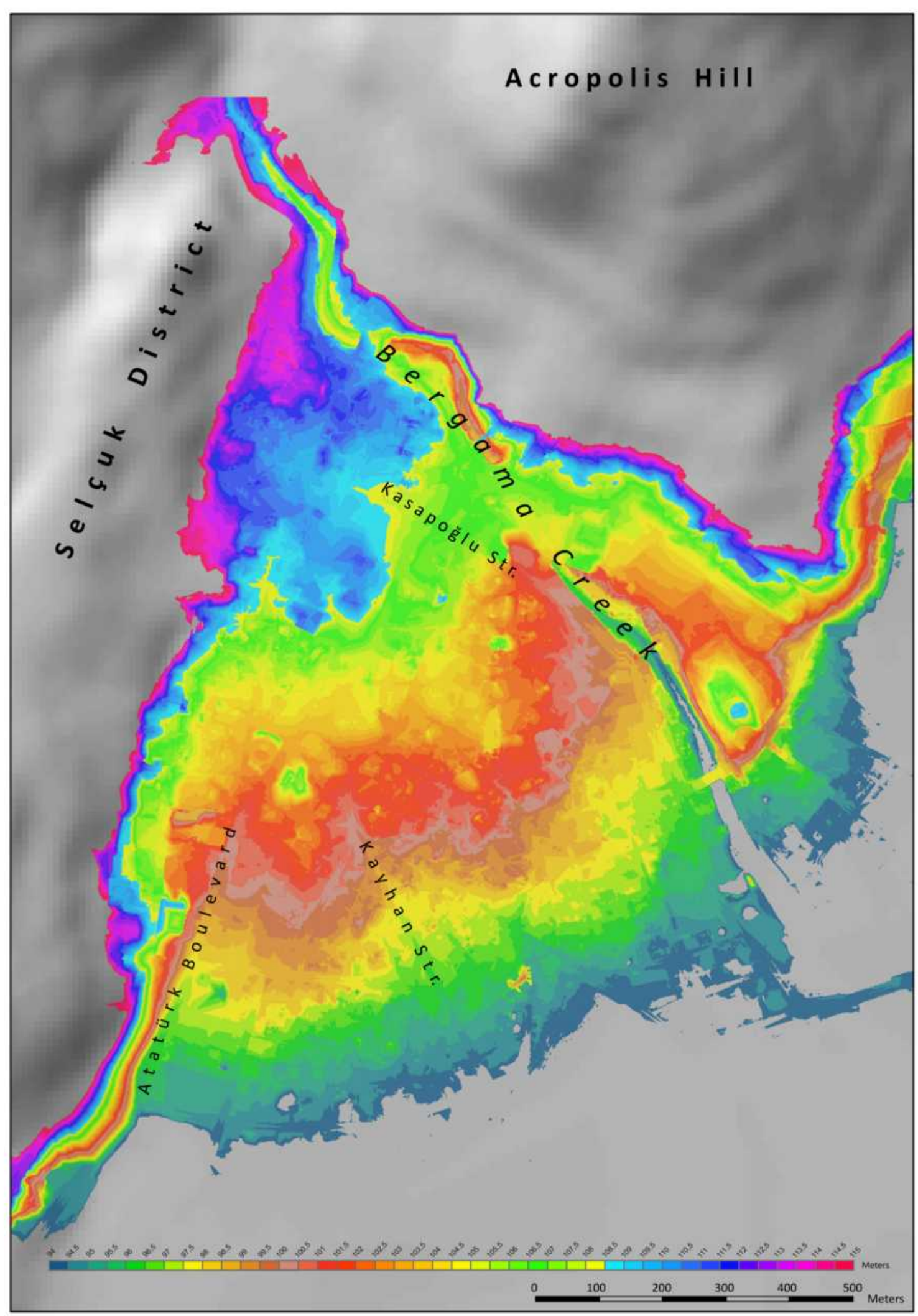

Figure 7. Proximal part of Bergama alluvial fan 


\subsection{Medial Fan}

The medial fan of the alluvial fan by starting from the arc drawn by the approximately $95 \mathrm{~m}$ izohipsi has been progressing as far as the arc drawn by the approximately $74 \mathrm{~m}$ contour line, which passes just south of the Çatalhöyük tumulus. The symmetry of the alluvial fan has been beginning to deteriorate in this section. East of the tumulus of Çatalhöyük (in the central parts of the alluvial fan) between Çatalhöyük and Maltepe tumulus, the cone descends from north to south with an almost unchanged slope on the western edge of the alluvial fan. In the East, in the south of Yarımtepe tumulus, Bergama Creek has been joining Kestel Creek. In this area, due to the alluviums brought by both streams, the symmetry of the alluvial fan has been deteriorating and has been expanding. The continuation of the current sedimentation in this part of the alluvial fan and the contribution of the Kestel stream to the formation process of the cone with its sediments accelerated the development of the cone in this area. For this reason, the cone has been spreading over a wide area in the east.

\subsection{Distal Fan}

The distal section where the alluvial fan joins the plain floor starts at a height of roughly $70-74$ $\mathrm{m}$. This point is limited by the levees formed by the Bakırçay river which flows west to the north of Sindel village in the south. This part of the alluvial fan is characterized by the levees formed by very fine sediments brought by the Bergama river in the west and the Bergama stream in the east, together with the Kestel stream. In the digital elevation model created from LIDAR data, three different stream levels, one belonging to the current Bergama stream, and the other two belonging to the previous beds can be distinguished. The westernmost levee is fainter, while the eastern ones are more prominent. The fact that the easternmost levee belongs to the current bed gives the impression that the ages of the stream beds indicated by the levees are getting younger from west to east.

\section{Results and Discussion}

The alluvial fan of Bergama is a conjunct result of the sedimentation process of Bergama and Kestel creeks that run through the south direction in the southern slopes of Madra Dağ1 and extended from Madra Dağ 1 to the North to Yunt Dağ1 to the South. The size of the fan in the North-South direction is more than $5 \mathrm{~km}$ while in the East-West direction it is about $4 \mathrm{~km}$. Although the length and the size of the Bergama and Kestel creeks' catchment areas are small, the size of the alluvial fan is disproportionally bigger. It mainly results from the fact that lithological settings of the catchment area consist mainly of the loose Neogene aged igneous and sedimentary material as well as loose sands which are the end product of the exfoliation process of Paleocene aged granodiorite formations (Figure 6).

Although Bergama and Kestel creeks have been created the Bergama alluvial fan, the main hydrological agent in the area is the Bakırçay River, which runs in East-West direction in front of the alluvial fan. The formation of the alluvial fan has been pushed, straiten and fixed the Bakırçay River between the southern tips of the fan and northern slopes of the foothills of Yunt Dağ1.

Besides the sedimentological processes of the creeks and rivers, the tectonic activities, which have created the Bakırçay Horst Graben system, have also affected the morphography of the alluvial fan. The most affected part of the fan from tectonic activities is the proximal fan, since it is the oldest and closest part to the tectonically risen side of the horst graben system. As a result of the tectonism;

1. The alluvial fan has been tilted to the south with the relative higher slope degrees at the proximal fan.

2. The Bakırçay creek has been embedded in its bed, so the sedimentation of the proximal fan has been discontinued.

3. As a result of tectonic rise and tilting of the proximal fan, the sedimentation had been ceased here and the proximal fan began to be eroded by surface waters, so the new and small creeks have been formed on the surface (Figure 7). 
The small creeks resulting from the water surface erosion are no longer visible beneath the $95 \mathrm{~m}$ contour line. Morphography of the alluvial fan between $95 \mathrm{~m}$ and $75 \mathrm{~m}$ contour lines is very dull; and the monotony is interrupted only by the human made mounds such as Maltepe and Yığmaca Tepe at the west and the relative rise at the east where Kestel Creek join to the Bergama creek. Relative rise on the ground seems like a secondary fan formation due to rapid sedimentation as a result of the join of the creeks.

To the south of Maltepe Mound approximately beneath the $75 \mathrm{~m}$ contour line the distal part of the alluvial fan has radially stretches from east to west. This distal part of the fan also constitutes the transition zone of the alluvial fan to the flood plain of Bakırçay. As the most recent part of the alluvial fan, it is the most sedimentological dynamic part. The formation of the alluvial fan in the distal part must have continued till the early 20th century when drainage and irrigation channel network were constructed and prevented the sedimentation. Since the slope angle is very small here, it is very hard to observe the topographical change with conventional methods. Fortunately, the airborne LiDAR data has provided the necessary high-resolution topography map to perform morphometric analysis at the distal part of the fan (Figure 8).

One of the most remarkable features in the DEM from LiDAR data in the distal part of the alluvial fan is the sub alluvial fan in the southwest (Figure 8; [A]), which must be created by the Bergama creek while it had been flowing at the east apart from the Kestel creek. The two sets of levees of old creek courses are also visible in Figure 8 ((a1), (a2)). Approximately 1-2 $\mathrm{km}$ to the east there are also three sets of levees belongs to old courses of the Bergama creek. Since this part is much closer to the actual river course, they must have been created by the old creek course or/and temporary recent flood channels. The most prominent set of levees is of course by the recent course of the joint stream of Bergama and Kestel creeks (Figure 8; (c)). Initially it stretches from NW-SE direction, then it draws an arc and turns to SW just before the Bergama creek joins to Bakırçay River. At the southern end of the alluvial plain, where the Bakırçay Rivers run along the foothills of Yunt Dağı, this zone stretches the levees of the same river (Figure 8; (d1)). The old river course of Bakırçay River and levees created by it at the eastern part of the map can be also observed (Figure 8, (d2)).

Formation of the Bergama alluvial fan has been straitened and fixed the Bakırçay River at its southernmost tip by the foothills of Yunt Dağı. Although rivers on flood plains consistently change their courses, the remnant of an ancient bridge on the course of the present Bakırçay River is the evidence of that fixation (Figure 8).

Between the slopes of the Bergama alluvial fan and levees of Bakırçay, there is a backswamp of the Bakırçay River, where the surface water has been accumulated and the old course of Bergama Creek had been flown parallel to the Bakırçay River to the west. Today the old course of creek and flood channels have been regulated for drain and used for agriculture.

As a high ground from the floods of Bakırçay River the alluvial fan of Bergama offers a perfect location for agriculture and settlement. While it is a safe haven from floods, it is also very close to the water to agriculture with its fertile and productive soil. There is no doubt that the settlement itself has been supported by the alluvial fan.

It is obvious that the surrounding slopes and proximal fan have been used as a residential district. Since the space in this part of the fan is very confined the plan of the city, it must follow the surface topography of the proximal fan. The streets must follow the natural small creeks created by the surface erosion, so the houses do not prevent to drain rainwater and let them flow through the streets. The legacy of this settlement pattern can be traced even today (Figure 7).

While the proximal fan along with the surrounding slopes has been used mainly for settlement, the medial fan has been used mainly for agricultural purposes, since it is far from the slopes and the swampy area of the distal fan.

The outer arc of the alluvial fan, which constitutes the distal fan, is also the border of agricultural rich alluvial fan with the swampy flood plain especially the backswamp beneath the levees of Bakırçay River. Since the access to the Bergama city from the south is obstructed by the swamps, it is important 
to understand the geomorphology of this side of the plain. Naturally, the relatively high ground of the natural levees provides strips for road networks.

According to the DEM acquired by the LiDAR data (Figure 8), there are two possible locations for the appropriate south connection with the Bergama city. Both of them have crossed the swampy area at their narrowest places. The first one is at the east following the present Bergama Creek natural levees (Figure 8 ; (c)). The second one is approximately $2 \mathrm{~km}$ from the west from the first one. This one has entered to the backswamp on the levee designated as (b1) in Figure 8 and continues to the south while passing the Bakırçay River at the ancient bridge near the Sindel village.

\section{Acknowledgement}

We would like to thank the General Directorate of Mapping for providing airborne LiDAR data to our universities, public institutions and organizations. 


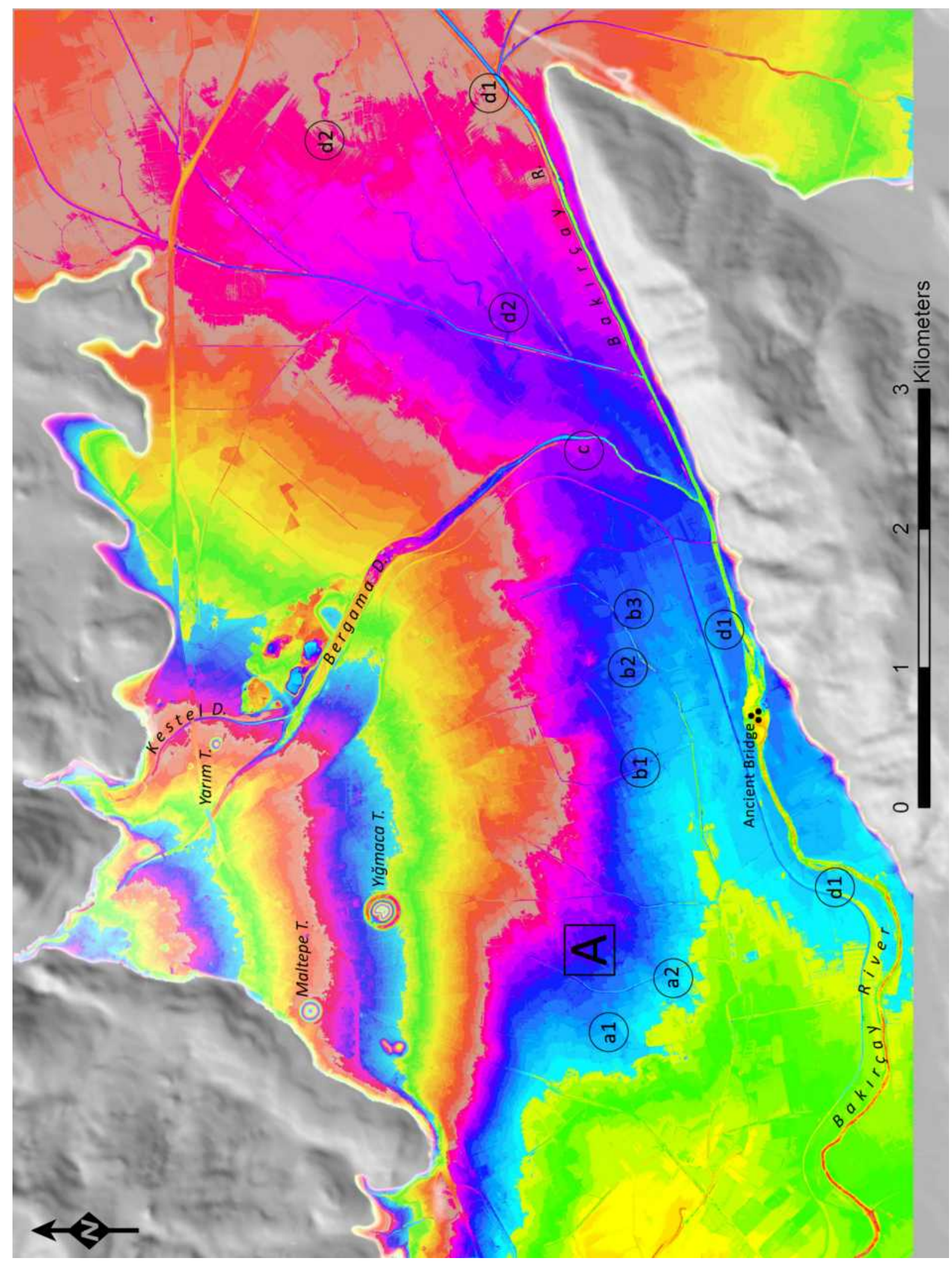

Figure 8. Topographical map of Bergama alluvial fan (each color shade represents $0,5 \mathrm{~m}$ decrease to north) 


\section{References}

1. Blikra, L., Nemec, W., Postglacial colluvium in western Norway: depositional processes, facies and palaeoclimatic record. Sedimentology 1998, 45(5), 909-959.

2. Dühnforth, M., Densmore, A., Ivy-Ochs, S., Allen, P., Kubick, P., Timing and patterns of debris flow deposition on Shepherd and Symmes creek fans, Owens Valley, California, deduced from cosmogenic 10Be Journal of Geophysical Research: Earth Surface 2007, 112

3. Tomczyk, Aleksandra M., Ewertowski, Marek W., Stawska, Monika, Rachlewicz, Grzegorz, Detailed alluvial fan geomorphology in a high-arctic periglacial environment, Svalbard: application of unmanned aerial vehicle (UAV) surveys Journal of Maps 2019, 15(2), 460-473.

4. Kraft, John C, Bückner, Helmut, Kayan, Ilhan, Engelmann, Helmut, The geographies of ancient Ephesus and the Artemision in Anatolia Geoarchaeology 2007, 22(1), 121-149.

5. Allen, S K, Schneider, D, Owens, I F, First approaches towards modelling glacial hazards in the Mount Cook region of New Zealand's Southern Alps Natural Hazards and Earth System Sciences 2009, 9(2), 481-499.

6. Cavalli, Marco, Tarolli, Paolo, Marchi, Lorenzo, Dalla, Fontana, Giancarlo, The effectiveness of airborne LiDAR data in the recognition of channel-bed morphologyCATENA 2008, 76(3), 249-260.

7. McKean, J, Roering, J, Objective landslide detection and surface morphology mapping using high-resolution airborne laser altimetry Geomorphology 2004, 57(3-4), 331-351.

8. Storesund, R, Minear, J, Evaluation of ground-based LiDAR for use in fluvial geomorphology and river restoration AGUFM 2006

9. Lefsky, M. A., Cohen, W.B., Parker, G.G. Harding, D.J., Lidar remote sensing for ecosystem studies, BioScience 2002, 52, 14-25

10. Mutlu, M., Popescu, C.S., Stripling, C., Spencer, T., Mapping surface fuel models using lidar and multispectral data fusion for fire behavior, Remote Sensing of Environment 2008, 112(1), 274-285

11. Naesset, E., Gobakken, T., Estimating forest growth using canopy metrics derived from airborne laser scanner data, Remote Sensing of Environment 2005, 96, 453-465

12. Popescu, S.C., Estimating biomass of individual pine trees using airborne lidar, Biomass and Bioenergy 2007, 31, 646-655

13. Bufton, J.L., Garvin, B., Cavanaugh, J.F., Ramoz-Izquierdo, L., Clem, T.D., Karabill, W.B., Airborne LIDAR for profiling of surface topography, Optical Engineering 1991, 30, 72-78.

14. Meng, X., Currit, N., Zhaog, K., Ground Filtering Algorithms for Airborne LiDAR Data: A Review of Critical Issues, Remote Sens. 2010, 2, 833-860

15. Baltsavias, E., A comparison between photogrammetry and laser scanning, ISPRS J. Photogramm. Remote Sens. 1999, 54, 83-94.

16. Sithole, G., Vosselman, G., , AReport: ISPRS comparison of filters. Department of Geodesy, Faculty of Civil Engineering and Geosciences, Delft University of Technology, The Netherlands 2003

17. Lloyd, C.D., Atkinson, P.M., Deriving DSMs from LiDAR data with kriging, International Journal of Remote Sensing 2002, 23, 2519-24

18. Gonçalves-Seco, L., Mirand, D., Crecent, F., Farto, J., Digital terrain model generation using airborne LiDAR in a forested area Galicia, Spain. In. In Proceedings of 7th International symposium on spatial accuracy assessment in natural resources and environmental sciences, Lisbon, Portugal,;Lisbon, Portugal, 2007; pp. 169-80.

19. Kobler, A., Pfeifer, N., Ogrinc, P., Todorovski, L., Oštir, K., Džeroski, S., Repetitive interpolation: a robust algorithm for DTM generation from aerial laser scanner data in forested terrain, Remote Sensing of Environment 2007, 108, 9-23.

20. Lee, H.S., , A hybrid model for DTM generation from LiDAR signatures. Ph.D. thesis, Department of Electrical and Computer Engineering, Mississippi State University. 2004

21. Wack, R., Wimmer, A., Digital terrain models from airborne laser scanner data - a grid-based approach , International Archives of Photogrammetry, Remote Sensing, and Spatial Information Sciences 2002, 34 (3/B), $293-96$

22. Lloyd, C.D., Atkinson, P.M., Deriving ground surface digital elevation models from LiDAR data with geostatistics , International Journal of Geographical Information Science 2006, 20, 535-63

23. Optech, LiDAR Test Report of TURKEY 2014-A

24. Barber, C.P, Shortridge, A.M., Light detection and ranging (LiDAR)-derived elevation data for surface hydrology applications; East Lansing, MI: Institute of Water Resource, Michigan State University, 2004. 
25. Stoker, J.M., Greenlee, S.K., Gesch, D.B., Menig, J.C., CLICK: the new USGS center for LiDAR information coordination and knowledge, Photogrammetric Engineering and Remote Sensing 2004, 72, 613-16

26. Romano, M.E., Innovation in LiDAR processing technology , Photogrammetric Engineering and Remote Sensing 2004, 70, 1202-206 